\title{
O Jornalismo Cultural e seus vínculos com o jornalismo feminino: a cultura entre as últimas tendências da moda e a crítica literária
}

\author{
The Cultural Journalism and its links with the female journalism: culture among \\ the latest fashion trends and literary criticism
}

\author{
Ana Carolina Rocha Pessôa Temerl \\ (anacarolina.temer@gmail.com) \\ Mônica Rodrigues Nunes 2 \\ http://dx.doi.org/10.5216/cei.v14i1.21505
}

\begin{abstract}
Resumo
Este texto apresenta uma discussão sobre a evolução do "jornalismo cultural", o espaço conquistado em diferentes mídias (jornal, revista, televisão e Internet) e seu papel na atualidade. Também se buscou entender os vínculos entre imprensa cultural e imprensa feminina ou voltada para o público feminino, cuja proximidade mostrou-se presente em diversos segmentos, em diferentes períodos da imprensa brasileira.
\end{abstract}

Palavras-chave: Jornalismo cultural. Imprensa feminina. Estudo em mídia.

\begin{abstract}
This essay presents a discussion on the evolution of what is known as "cultural journalism", the piece of different medias (newspapers, magazines, television and Internet), as well as its current role. It also sought to understand the bonds between cultural press and female press, or that which is aimed at the female public, whose proximity shown itself present in several branches, in different eras of Brazilian press.
\end{abstract}

Keywords: Cultural Journalism. Female Journalism. Media Studies.

\footnotetext{
${ }^{1}$ Professora do Programa de Pós-graduação da Faculdade de Comunicação e Biblioteconomia - FACOMB, da Universidade Federal de Goiás. Doutora e mestre em Comunicação Social pela Universidade Metodista de São Paulo, Especialista em Sociologia pela Universidade Federal de Uberlândia e Bacharel em jornalismo pela Escola de Comunicação da Universidade Federal do Rio de Janeiro (UFRJ). Diretora Regional da Intercom - Sociedade Brasileira de Estudos Interdisciplinares da Comunicação. Coordenadora do GT Estudios de Periodismo da ALAIC - Assossiación Latinoamericana de Investigadores de La Comunicación. Autora dos livros Notícias \& Serviços nos telejornais da Rede Globo. Editora Sotese, Rio de Janeiro, 2002; e Para Entender as Teorias da Comunicação, Edufu, 2009, e A televisão em busca da Interatividade, Casa das Musas, 2009.

${ }^{2}$ Jornalista. Mestre e Doutora em Comunicação Social pela Universidade Metodista de S. Paulo e docente do lato sensu em Jornalismo Cultural da mesma universidade. É autora de artigos sobre análises de objetos do jornalismo cultural entre eles: "O suplemento Literário de O Estado de S. Paulo e a cobertura do mercado editorial (1957-1964)" e "Livros no jornal - a Ilustrada e o mercado editorial" publicados no livro "Fusões: cinema, televisão, livro e jornal", organizado por Antonio de Andrade e Sandra Reimão, Editora Metodista, 2007.
} 


\section{Introdução}

A capacidade do ser humano de adquirir, processar e compartilhar informações foi fundamental para o desenvolvimento do homem, tanto no que diz respeito a sua organização social e política, quanto as suas manifestações culturais. Essa capacidade, que se desenvolve em diferentes formas e conteúdos, ganhou novas e complexas relações na sociedade industrial moderna. Neste ambiente, cuja marca é a presença dos meios de difusão de informação e de comunicação massivos ou em larga escala, a informação perdeu as características aleatórias que determinavam a circulação de uma notícia ou um boato na praça pública, e passou a ser concebido a partir de uma produção planejada e artificialmente acelerada, em muitos aspectos semelhante a dos demais produtos industrializados e orientados em função do mercado consumidor.

Os novos processos produtivos impostos pelas mídias alteram não apenas a quantidade das informações que chegam ao grande público, como também a qualidade dessa informação: na sociedade industrializada moderna as dinâmicas sociais englobam complexas relações com a mídia e com os limites impostos pela produção industrializada da informação.

Nesse aspecto, a "produção" do material jornalístico é exemplar. Ainda que o senso comum aponte para a noção de que o jornal é o espaço da notícia, do que é essencialmente novo e não conhecido nos dias anteriores ${ }^{3}$, a própria concepção de que é preciso "produzir" para cada novo exemplar um material "novo", exige a implantação de complexas estratégias para a obtenção de informações sempre inéditas (ou aparentemente inéditas) e significativas para o leitor receptor. De fato, as rotinas de trabalho desenvolvidas pelos jornalistas visam não apenas garantir que fatos importantes estejam presentes nas manchetes jornalísticas; como também seduzir o leitor a partir da falsa noção de que estão vendo algo novo e de significativa importância, mesmo quando estas duas condições estão ausentes.

Na prática, na atividade jornalística, essa questão resulta na aceitação de que o jornalismo vai além das notícias, ou das matérias factuais, e se compõe também de espaços, temas e assuntos cuja cobertura pode ser previamente programada (ou pautada).

Dentro de uma estratégia conscientemente elabora para garantir que um material de interesse do leitor mesmo nos dias/edições jornalísticas em que as notícias não tragam informações novas e/ou relevantes para o grande público.

\footnotetext{
${ }^{3}$ Ainda que o termo jornal seja aplicável a veículos de diferentes periodicidades, a origem da palavra remonta a idéia de "jornada" ou de um ciclo diário completo, o que justifica a referência citada.
} 
Além deste aspecto, a diversificação dos veículos e a segmentação do público abriram espaços para novos temas, assuntos, possibilidades, enfim, novos conteúdos destinados a novos segmentos do público. De uma forma geral, essa estratégia seguiu caminhos diferentes. Enquanto para alguns veículos o caminho foi a segmentação e a especialização, para alguns grandes jornais, ou mesmo para outros veículos diários, a estratégia de sedução do leitor/receptor do material informativo-jornalístico pela imprensa passa, também, pela diversificação dos assuntos abordados.

Neste contexto de múltiplos temas e enfoque, a cultura, como parte do caráter humano e um elemento essencial para a vida social, não foi ignorada. De fato, ela é um dos conteúdos que, em seus diferentes aspectos, compõe a lista de temas e assuntos previamente catalogados pelo jornalismo, e que se constituem em uma espécie de enfoques recorrentes no jornalismo.

A imprensa, primeiro por meio dos jornais impressos e posteriormente do rádio e da televisão, abriga espaços específicos para divulgar produtos culturais, tanto na íntegra quanto através de anúncios, notícias e análises destes produtos. Os modernos jornais diários e as emissoras de televisão ratificam esse princípio através dos cadernos de cultura ou dos programas destinados a comentar, mostrar e analisar cultura.

Nesse sentido, a proposta desse artigo é uma discussão sobre a evolução do "jornalismo cultural", visando discutir o espaço que conquistou no interior de diferentes mídias, seus vínculos com o jornalismo feminino ou destinado ao público feminino e o seu espaço atualmente na mídia.

\section{O espaço da cultura no jornalismo}

As mudanças de comportamento da sociedade, cada vez mais estratificada e formando grupos que, mesmo se inter-relacionando, têm objetivos, interesses, gostos e costumes diferenciados, obrigou a imprensa a criar produtos editoriais diversificados para atender a uma camada maior do público ou, no caso de setores mais abrangentes do jornalismo, diversificar os conteúdos para atingir uma parcela maior do público.

Essa tendência da segmentação do público e a exigência de conteúdos diversificados ocorreram em paralelo às fusões dos conglomerados da área comunicativa. Uma explicação para essa questão está no fato de que, nos dias atuais, os custos e as características da produção jornalística tornaram indispensável à determinados setores da indústria da informação ampliar e fidelizar os anunciantes e o seu público. Um dos caminhos encontrados pela indústria ou uma das estratégias adotadas por elas foi oferecer um leque diversificado de conteúdos ao leitor. Dentro 
desta estratégia a idéia de segmentação dos conteúdos, a busca por novos leitores e de novos públicos, tornaram-se palavras mágicas, "mantras" a serem seguidos pelas mídias que buscam crescer.

Nos jornais impressos, um dos caminhos para a segmentação ocorreu por meio da criação de diferentes "suplementos" ou cadernos com temas ou assuntos específicos, indicados para a leitura de segmentos igualmente específicos, em uma proposta que entendia que a "cadernização" era a melhor estratégia para, a partir de um mesmo produto jornalístico, falar com diversos públicos.

Essa ação permitiu o desenvolvimento do jornalismo especializado, um modelo de conteúdo relacionado a uma lógica empresarial que vê na segmentação do mercado uma estratégia eficiente para atingir grupos diferenciados, mas com alguns interesses em comum. Além de ser uma ferramenta eficiente para a obtenção de lucro para os conglomerados midiáticos, a segmentação facilita a busca por uma identificação com o estilo de vida do leitor e por uma linguagem mais aproximada com o seu universo.

Neste conjunto, o jornalismo especializado funciona como uma resposta à necessidade destes grupos ou audiência específica por informações direcionadas/especializadas. A criação desses espaços diferenciados também abriu possibilidades de experimentações de linguagens e até da introdução de novas rotinas de produção, novas formas de elaborar pautas jornalísticas. Nesse contexto, o jornalismo cultural e o jornalismo feminino, ou impressa feminina, muitas vezes se encontraram compondo cadernos "especializados" nos quais os assuntos ligados ao dia a dia da mulher, e particularmente da dona de casa, se misturavam às resenhas e às críticas teatrais, compondo o chamado estilo magazine (VILAS BOAS, 1996).

No entanto, essa inter-relação entre o jornalismo cultural e a imprensa feminina nem sempre é muito clara mesmo para os editores e redatores destes cadernos ou revistas, e constitui-se em um conjunto de conteúdos que ainda precisa ser melhor explorado.

Nos jornais diários brasileiros a proximidade entre os temas literários e/ou culturais e os temas femininos, em diferentes momentos, foram bastante evidentes. Em cadernos ou suplementos, em geral de periodicidade semanal, voltados para o público feminino a publicação de poemas, sonetos, contos e outros gêneros literários eram muito freqüentes. A autoria das produções literárias se mesclava entre senhoras do lar e autores consagrados ou estreantes.

Entre outros exemplos da proximidade entre imprensa cultural/literária e feminina podemos citar os suplementos culturais - também intitulados "suplementos literários" - publicados na 
imprensa brasileira entre as décadas de 1920 e 1970. Estas publicações editavam, além de matérias sobre o universo cultural e produções literárias, conteúdos muito específicos do universo feminino, como: culinária, comportamento, beleza e moda. Em geral, os assuntos da mulher eram publicados em páginas com títulos próprios. Na imprensa paulistana há muitos exemplos desta característica dos suplementos literários". Destacamos o "Suplemento: Nas letras, Nas artes e No lar e na sociedade", do jornal Correio Paulistano, lançado em dezembro de 1958. Este suplemento era composto por oito páginas, dedicando metade delas aos assuntos literários e culturais e metade, aos assuntos femininos.

Outros suplementos literários da imprensa paulistana publicavam seções ou páginas para os assuntos femininos, entre eles: o "Suplemento" da Folha da Manhã, que a partir de 1937 passou a publicar a página "Elegância e Conforto"; o "Suplemento Literário" do Diário de S. Paulo, que desde o seu lançamento publicava na página três a seção "Mulher, Criança e Lar"; e, o "Suplemento Pensamento e Arte" do Correio Paulistano que, em 1953, passou a publicar a "Página Feminina".

Outro suporte do jornalismo cultural que já teve bastante proximidade com jornalismo feminino é o caderno diário de cultura. No Brasil, estas publicações surgiram na década de 1950, tendo tornado uma prática comum, nos jornais diários, a partir dos anos de 1980.

Um dos primeiros cadernos diários voltados para o universo cultural de nossa imprensa, a "Folha Ilustrada" dos jornais Folha da Noite e Folha da Tarde (a partir de 1960 apenas Folha de S. Paulo), quando criado, segundo Cassiano Eleck Machado, foi criado para atender o público feminino: "José Nabantino tinha a idéia de que o primeiro caderno ficaria com o marido e, o segundo, a Ilustrada, com a mulher" (2001, p.18).

Nos primeiros anos de publicação do caderno "Folha Ilustrada" (em meados da década de 1970, o caderno teve seu nome alterado para apenas "Ilustrada") este não se detinha como observador exclusivo de temas culturais. Matérias sobre beleza, artes, literatura, moda, turismo, ciências, fofocas, Rádio e TV, horóscopo, saúde, entre outras, compunham seu noticiário.

Como já dito, a segmentação dos temas dentro dos jornais forçou a criação de novos cadernos. Nesta direção, os cadernos culturais de diversas publicações passaram a ter conteúdo mais definido; publicando quase que exclusivamente assuntos relacionados à artes e à espetáculos.

\footnotetext{
${ }^{4}$ Sobre suplementos literários e cadernos culturais publicados na imprensa paulistana ver NUNES, Mônica de Fátima Rodrigues. Paulicéia literária: páginas e suplementos literários na imprensa paulistana (1920-1964). 2007. Tese (Doutorado em comunicação social) - Universidade Metodista de S. Paulo.
} 
$\mathrm{Na}$ contramão desta segmentação dos cadernos culturais, atualmente, muitos jornais preferem publicar cadernos de conteúdos mais abrangentes, em geral, intitulados de cadernos de variedades. Estes têm por característica publicar um leque maior de assuntos - artes, espetáculos, beleza, diversão, curiosidades etc - não se restringindo apenas aos temas normalmente encontrados em um caderno cultural; muitas vezes recheados de matérias relacionadas ao universo feminino.

\section{A revista feminina, a imprensa para o público feminino e a revista cultural/literária}

Fatores semelhantes àqueles que impulsionaram o desenvolvimento dos jornais fizeram com que, em um movimento paralelo, ocorresse o crescimento das revistas femininas no Brasil. No entanto, o surgimento de um setor específico, voltado para a imprensa feminina obedeceu a uma dinâmica própria, que se iniciou além das nossas fronteiras.

Os registros históricos apontam o Lady's Mercury, que circulou na Inglaterra em 1693, como o mais antigo periódico destinado exclusivamente às mulheres. Após o seu surgimento, vários títulos continuaram a atender o público feminino. Foi o caso, entre outros, do Ladies' Diary, veiculado por mais de um século. A idéia de publicar títulos voltados para o público feminino também alcançou rapidamente outros países _ Akademie der Grazien, Journal fur Deutsche Frauen, Alemanha, Die Elegant, Áustria; Toillete-1770, Biblioteca Galante-1775, França; Giornalle della Donn -1781, Itália (Buitoni, 1986, p.25). Estes veículos tinham em comum o fato de destinarem um amplo espaço para assuntos culturais, como poesia e textos em prosa, mas traziam também receitas culinárias, comentários sobre moda e, eventualmente um consultório sentimental, ou algum tipo de análise/debate sobre as questões femininas (cuidados do lar, educação dos filhos, entre outros).

A quebra deste modelo só ocorreu em 1863, quando um editor norte-americano, Mr. Butterick lançou o molde para a confecção de roupas encartado nas revistas e impresso em série. Ainda assim, em 1928, quando o Ladies' Magazine consolidou o termo "magazine", as revistas femininas ainda ofereciam principalmente muito material para leitura (prosa e poesia), algumas notícias e serviço.

No Brasil, a situação de colônia que já havia dificultado a chegada da imprensa, também foi um empecilho para o surgimento das revistas femininas. O primeiro periódico feminino brasileiro foi lançado no Rio de Janeiro em 1827: o Espelho Diamantino. A ele seguem-se diversos outros: $O$ Espelho das Brasileiras (publicado em 1831 em Recife), Jornal de Variedade (1935), Relator de Novelas (1838) Correio das Modas (1939), Espelho das Bellas (1941), A Marmota (1949), o 
primeiro a trazer litografias impressas no Brasil. (BUITONI, 1986: 37 e A Revista no Brasil (ABRIL, 2000, p. 232).

Neste início, muitos veículos reservavam um espaço considerável para a literatura, trazendo histórias em capítulos. Kátia de Carvalho, na tese intitulada "Cidade das Revistas" (UFRJ) aponta que no Brasil do começo do século passado as revistas literárias e femininas se confundiam. Em muitos casos as revistas resultavam de iniciativas "culturais" das senhoras da sociedade, uma camada elitizada e letrada da burguesia nacional, que demonstrava sua erudição nos saraus e encontros sociais, e que necessitavam de um veículo para divulgar sua produção literária. Em outros casos, como no Armazém de Novellas Escolhidas ou Novelista Brasileiro (ambos 1951) existiam fascículos encartados, eventualmente utilizados para a publicação de romances folhetinescos.

De uma forma geral, é possível dizer que embora fosse inicialmente destinada às mulheres de alto poder aquisitivo, que viam nas revistas uma forma de entretenimento cultural de boa qualidade, a imprensa feminina brasileira foi, pouco a pouco, se democratizando, quase sempre em um ritmo que acompanhava o aumento do poder de compra do público feminino. Ou seja, na medida em que as mulheres conquistavam novos postos de trabalho, as revistas passavam também a ser vendidas em lojas comerciais e livrarias, acompanhando a democratização da moda.

No Brasil essa mudança se acentuou com A Revista da Feminina, (1914) título que introduz um esquema comercial no setor. $\mathrm{O}$ fenômeno acompanhou o crescimento das indústrias relacionadas à mulher, a ampliação da classe média e o crescimento do mercado interno. Um novo impulso aconteceu no final da Segunda Grande Guerra, quando a indústria gráfica ficou mais sofisticada e tornou-se capaz de dar suporte às edições coloridas e quase luxuosas. No Brasil, títulos como Grande Hotel, da Editora Vecchi e Capricho, da Editora Abril, começaram a publicar fotonovelas. Alguns anos depois, a revista Cláudia inaugurou um novo estilo, sofisticando ainda mais o setor.

Mas antes que a primeira revista feminina, editada no Brasil, começasse a circular, títulos de revistas culturais/literárias já constavam na lista de publicações editadas no país. A primeira a circular oficialmente, no Brasil, foi As variedades ou Ensaios de Literatura, publicada em 1812, saindo apenas dois números. Variedades foi um dos veículos criados pelo governo joanino para "neutralizar" a ação do Correio Brasiliense (periódico assinado por Hipólito da Costa que entrava clandestinamente no Brasil; desde junho de 1808). 
Quanto ao perfil editorial de Variedades, segundo Nelson Werneck Sodré, a proposta era “divulgar discursos, extratos de história antiga e moderna, viagens, trechos de autores clássicos, anedotas, etc.” [...]. E completa: “[Variedades] foi ensaio frustrado de periodismo de cultura destinava-se a mensário - que o meio não comportava” (1999, p.30).

Depois de Variedades, várias revistas culturais/literárias surgiram no mercado brasileiro. Principalmente nas primeiras décadas do século $\mathrm{XX}$, quando a imprensa diária já avançara na transformação em empresa estruturada em molde industrial. Nesta transição, o conteúdo dos jornais sofreu modificações: o importante passou a ser o fato político e não mais a matéria literária - o espaço para as colaborações literárias foi acentuadamente reduzido; uma nova forma de escrita começava a ser exigida (textos mais curtos e diretos).

A perda de espaço nos jornais para a publicação de trabalhos literários e a ausência de editoras contribuíram para o surgimento de novas revistas literárias (ou culturais). A revista passou a ser o espaço que o literato tinha para publicar seus trabalhos de criação. Mas poucas revistas conseguiam alcançar número significativo de edições; muitas delas, "nascidas do entusiasmo e idealismo da boêmia das confeitarias da inicial República das Letras" (Martins, 2001, p. 67). Entre as que conseguiram se firmar - com periodicidade regular - citamos A Revista do Brasil, editada por mais de 70 anos (1916 a 1990), divididos em diferentes fases.

Mas foi a partir da década de 1990 que surgiram parte das revistas culturais atualmente em circulação no país. Entre elas, citamos: Revista Bravo! e Revista Cult, em circulação desde 1997 e, Revista Piauí, lançada em 2006.

Também verificamos o surgimento de revistas que dedicam seu conteúdo a único tema. Como é o caso da revista EntreLivros, lançada em 2005, que, como o próprio título conduz, apresenta cobertura focada no universo dos livros.

Muito do que estas revistas - Bravo!, Cult, Piauí e EntreLivros - apresentam ao longo de suas edições coincide em grande parte com o perfil de edições, de mesmo gênero, publicadas em diferentes épocas. Nelas se publicam entrevistas, reportagens, ensaios, críticas, resenhas, trabalhos de criação literária, entre outros. Atualmente estas quatro revistas são consideradas de circulação nacional e todas elas possuem sites na Internet que possibilitam a leitura, entre outros textos, de conteúdos publicados nas edições impressas. São eles: Bravo! (http://bravonline.abril.com.br/); Cult (http://revistacult.uol.com.br/website/); Revista Piauí http://www.revistapiaui.com.br/; e EntreLivros (http://www2.uol.com.br/entrelivros/) 
A Internet também possibilitou um novo segmento para o jornalismo cultual. Revistas virtuais de arte e cultura (ou revistas eletrônicas como são comumente intituladas por seus idealizadores) começaram a ser publicadas na rede principalmente a partir do ano 2000. Em 2000 foram lançadas as revistas: Revista Aliás (http://www.aliasrevista.net/) dirigida por Elaine Pauvolid; Só Cultura (http://www.socultura.com/), coordenada por José Guilherme Said Pierre Carneiro; Digestivo Cultural, dirigida por Julio Daio Borges. Algum tempo depois surgiram: Revista Etcetera (http://www.revistaetcetera.com.br/), criada em 2001 por Sandro Eduardo Saraiva (editor de conteúdo e redator), Douglas J. Silva (editor de arte e webdesigner), Adriana Aranha e Marici Silveira (conselho editorial e redação); Revista Speculum (http://www.speculum.art.br/), com início 2003, editada por Amanda França, Danilo Corsi, Marcelo Hessel, Renato Roschel; e, Revista Pronto! (www.revistapronto.com.br), inaugurada em 2006, editada por Clodoaldo Teixeira.

A maior parte das revistas virtuais de arte e cultura apresentam características similares às revistas impressas, com a publicação de seções fixas, colaboradores fixos. Nelas publicam-se notas, resenhas, crônicas, artigos, ensaios, entrevistas, críticas, etc sobre os mais variados temas: filosofia, literatura, artes plásticas, cinema, teatro, fotografia, TV, música, entre outros.

No entanto, apesar da Internet ser um veículo de maior flexibilidade quanto à atualização ou postagem de novos conteúdos, a periodicidade das revistas virtuais busca obedecer a calendários ("sempre que possível", como descrita em muitos editoriais) definidos por seus editores. Algumas revistas virtuais utilizam blogs para postarem conteúdos inéditos ou adicionais, como notas e comentários, que não obedecem a critérios de periodicidade, ou seja, uma seção que é mais flexível tanto para temas quanto para atualização.

\section{A cultura e o jornalismo "feminino"?}

Para entendermos a relação entre os cadernos culturais e a imprensa feminina é preciso também fazer uma análise do conceito de cultura. Embora alguns setores vinculem o termo a idéia da cultura de elite, das obras literárias clássicas e dos grandes espetáculos de ópera, na verdade a “Cultura não é a prática, nem simplesmente a descrição da soma dos hábitos de uma sociedade. Passa por todas as práticas sociais e suas inter-relações". (HALL in WOLF, 1987, p.94).

Ou seja, cultura é tudo aquilo que fazemos, vestimos, comemos, produzimos. Neste sentido, os veículos destinados ao público feminino são um grande espaço para representações culturais 
diversas, uma mega-vitrine esteticamente manipulada das culturas desejadas ou desejáveis para os públicos que se pretende atingir.

As revistas femininas trazem narrativas que atribuem significados míticos comuns à figura da mulher e do papel que elas desempenham na sociedade. As redes de figuras que se estampam nos textos verbais e visuais destas publicações contribuem também para definir papéis que sintetizam os modelos figurativos atribuídos à mulher, em que a leitora possa espelhar-se.

Ou seja, as revistas femininas fornecem dados importantes para entendermos a cultura de um determinado grupo social, além de influenciarem esses costumes.

Além disso, assim como a imprensa feminina, o Jornalismo Cultural é visto, sobretudo (por muitos leitores), como um serviço em que predomina o caráter orientador ou indicador, e se inclui no chamado "jornalismo de serviço". De fato, o termo jornalismo de serviço teve origem nos Estados Unidos e envolve uma expressão diretamente ligada as Revistas Femininas. Esse modelo de jornalismo tem como objetivo "poupar tempo e/ou dinheiro" para o receptor, funcionando como uma espécie de "guia" para o receptor, preparando-os para agir como consumidores racionais de produtos culturais e físicos, serviços e direitos sociais (BEZERRA, 1991). Enfim, trazendo todo um conjunto de informações necessárias às atividades humanas. Dessa forma, o serviço é um reconhecimento de que "em la edad de la información, la gente pueda necessitar 'menos información y mas guia"”. (DIEZHANDINO, 1994, p.77).

Na sociedade marcada pela influência da mídia, embora não seja possível dizer que a cultura tem vínculos diretos com relações econômicas, a mídia exerce sua força de influência nas relações político-econômicas expondo, através dos seus veículos, elementos desejáveis para a cultura, que reforçam aspectos importantes para as relações de produção e para a estrutura econômica. De fato, "Suas funções [(das revistas femininas)] não são transparentes, não visam apenas conselhos práticos ou lazer. No espelho da imprensa feminina, as imagens e as verdades são muitas” (BUITONI, 1986, p.5).

\section{O jornalismo cultural e o jornalismo feminino na televisão}

Se nos jornais o espaço dedicado às notícias sobre artes e espetáculos foi crescente, na TV não podemos afirmar o mesmo. Certamente, se houve um momento em que o assunto cultural foi destaque na programação da TV foi àquele relacionado aos primeiros anos de transmissões no Brasil, período em que a Televisão ainda não era um veículo de grande alcance e, o aparelho um 
objeto que poucos podiam comprar. Segundo Reimão (2006. p. 25) “a programação da televisão brasileira em seus primeiros anos é considerada sendo 'elitista': teatro clássico e de vanguarda, música popular e erudita e alguns poucos shows mais populares."

As tecnologias de veiculação e produção televisiva e o barateamento do aparelho de televisor permitiram que a TV se tornasse um veículo mais presente nos lares brasileiros, potencializaram a busca por audiência e lucro, o que alterou o perfil da programação das emissoras. $\mathrm{O}$ assunto cultural foi, aos poucos, dando lugar a programas de conteúdos mais populares e, eventualmente, até grotescos.

Com maior ou menor força essa é uma tendência que permanece, e neste início de século, a maioria das redes de televisão brasileira tem dedicado pouco espaço ao jornalismo cultural. Os telejornais dos canais abertos de televisão quase não abordam o tema cultural em suas edições, e principalmente nas suas edições noturnas. Eventualmente, matérias mais leves (incluindo aquelas relacionadas a arte e a espetáculos) são utilizadas nas edições diurnas e como estratégia para o fechamento das edições. ${ }^{5}$

Um telejornal que apresenta um perfil diferenciado é o Leitura Dinâmica, veiculado pela Rede TV. Este telejornal oferece, além do hard news, várias matérias relacionadas a artes e a espetáculos. Ressaltemos que, para os assuntos culturais, as matérias são dadas de forma breve, por meio de notas cobertas, sem qualquer apelo crítico. Uma agenda cultural das grandes capitais do País. Incluir uma breve agenda cultural nas sextas feiras também tem sido uma estratégia utilizada pelos telejornais locais do meio do dia, veiculados pela Rede Globo de Televisão e pelas suas emissoras afiliadas.

Das redes de TV de sinal aberto verificamos a presença de um programa voltado para a cobertura de artes e espetáculos. Trata-se do programa semanal Mosaico Bahiano veiculado semanalmente pela Rede Bahia de Televisão e TV Salvador, às 14h45 e às 19h15, respectivamente.

O jovem programa "Mosaico Bahiano" estreou em sete de julho de 2007. Caracterizado por seus idealizadores como uma revista eletrônica sobre "curiosidades, clipes, documentários, séries especiais, dicas de cinema, teatro, shows, artistas, visitas aos bairros, comportamento, turismo,

\footnotetext{
${ }^{5}$ Sobre essa questão, ver TEMER. Ana Carolina Rocha Pessôa. Notícias \& Serviços nos telejornais da Rede Globo. Rio de Janeiro: Sotese, 2002, que aponta em dados quantitativos que Cultura, Moda e Sociedade não alcançam índices significativos.
} 
cobertura de eventos da cidade [Salvador]" 6, o programa também visa ser um espelho dos acontecimentos culturais da Bahia.

Com exceção de alguns poucos programas editados por TVs de sinais abertos ou pagos, verificamos que os programas de jornalismo cultural na TV aparecem com maior regularidade nas TVs Educativas; revistas eletrônicas sobre artes e espetáculos estão presentes em várias delas.

Atualmente estão no ar as revistas eletrônicas culturais: Programa Agenda, da Rede Minas, desde 1987, com edições de segunda-feira a sábado; Programa Metrópolis, da TV Cultura, desde 1988, veiculado de segunda a sexta-feira, Estação Cultura, da TVE/RS (Fundação Cultural Piratini), de segunda a sexta-feira, Programa Re[Corte] Cultural, da TVE/Rio, também com edições de segunda a sexta-feira e reprise aos domingos, e Programa Soterópolis da TVE Bahia, com edições às quartas feiras e reprises às quintas feiras e aos domingos.

Outro diferencial das TVs Educativas é a veiculação de programas sobre literatura, música, cinema, teatro, etc. A periodicidade destes programas é variável, em média, com duas edições por semana (inédita ou reprises).

Embora os programas de televisão voltados unicamente para o Jornalismo cultural sejam poucos, o mesmo não pode ser dito sobre os programas voltados para o público feminino. De fato, ao mesmo tempo em que as revistas femininas se sofisticavam com títulos como $\mathrm{Cláudia}^{7}$, o modelo era copiado pela televisão, que usavam as fórmulas consagradas pelas revistas para veicular assuntos destinados ao público feminino, ao mesmo tempo em que se impunham na telinha impunha sua condição de veículo de maior prestígio entre os anunciantes.

Considerando os aspectos históricos, "desde os primórdios, a TV Tupi de São Paulo produziu programas dirigidos à mulher, especialmente à dona de Casa" (RIXA, 2000, p. 156). Entre os programas destinados ao público feminino veiculados pela TV brasileira, [na década de 1950], estão: a Revista Feminina, com Lolita Rios, e No mundo feminino, conduzido por Maria Lurdes Lebert e depois Elisabeth Dary. ${ }^{8}$ Também na década de 1950 foram veiculados programas como Maiôs á beira mar e Com a mão na massa (1957), ambos apresentados por Hebe Camargo, e Faça você mesma (LORÊDO, 2000, p. 56). ${ }^{9}$

\footnotetext{
${ }^{6}$ http://ibahia.globo.com/mosaico/default.asp

7 A Revista Cláudia se destaca pelas reportagens mais elaboradas e principalmente pelo amplo uso de ilustrações e fotografias coloridas.

${ }^{8}$ Só para citar exemplos de São Paulo e Rio de Janeiro, uma vez que este modelo se repetiam em várias emissoras locais.

${ }^{9}$ Programa de culinária e corte e costura que contava com a participação da culinarista Ofélia Anunciato.
} 
O modelo culinária e variedades culturais prosseguiu com apresentadoras como Edna Savaget (Edição Feminina), Xênia Bier, Ione Borges (RIXA, 2000) e Rosita Tomaz Lopes (LORÊDO, 2000, p.56) sempre com relativo sucesso e boa aceitação entre o público feminino, até que, na década de 1980, a Rede Globo lançou o TV Mulher, uma versão esteticamente mais elaborada e com um conteúdo diferenciado que incluía desde informações culturais até orientação sobre sexo e educação. O TV Mulher proporcionou um grande impacto sobre o gênero, mas na década de 1990, o modelo sofreu uma nova mudança com Note e anote, uma proposta que fez tanto sucesso que sua condutora, a apresentadora Ana Maria Braga, foi convidada a transferir-se com um alto salário para a Rede Globo de Televisão.

Sobretudo, o sucesso do modelo Note e anote deu origem a uma profusão de programas do mesmo estilo, quase sempre apoiados no tripé "culinária, artesanato e comportamento" 10 . Esses programas se distribuem pela grade de diversas emissoras, em versões matinais ou vespertinas, centrados em um apresentador e cenários simpáticos e domésticos, que incluem uma "cozinha" para a elaboração das receitas e uma "sala de visita", onde são realizadas entrevistas. Essas produções, nem sempre contempladas com índices de audiência significativos, tem em comum um baixo custo de produção e uma grande quantidade de merchandising, ou anunciantes que se inserem dentro do material produzido seja de forma clara ou subliminar (como por exemplo, o uso de determinada marca na elaboração dos produtos culinários).

Estes programas abrem espaço, também, para a divulgação de artistas de todos os tipos, desde o lançamento de discos, literatura e outros tipos de arte e artesanatos, além de entrevistas com diversos tipos de profissionais ligados ao mundo do espetáculo e personagens que por qualquer motivo estejam momentaneamente em evidência.

Todo esse conjunto, genericamente denominado "matérias de comportamento" pode também ser analisado na perspectiva do jornalismo cultural.

\section{O espaço do jornalismo cultural na imprensa feminina em a televisão: cultura, comportamento ou serviço?}

Entre os jargões utilizados pelos jornalistas, o termo "matéria de comportamento" diz respeito a vários tipos de matérias, em geral, elaboradas a partir de pautas que abordem hábitos

\footnotetext{
${ }^{10} \mathrm{O}$ termo será melhor definido em seguida.
} 
sociais (consumo, alimentação, educação, cultura, entretenimento, passeios, de viagens e muitos outros).

Apesar de sua imprecisão, o termo é bastante utilizado, a ponto de ser uma forma de "especialização" anunciada por alguns profissionais de imprensa. A entrevista de Fabrício Battaglinio, repórter da Rede Globo, esclarece um pouco mais o uso do termo:

Estou mudando do Departamento de Jornalismo para a Central Globo de Produção, mas não vou deixar de fazer jornalismo. No Mais Você posso confeccionar matérias de até 10 minutos, tempo de reportagem do Globo Repórter ou Fantástico. Já fiz matérias sobre as cafeterias e o hábito do brasileiro de deixar tudo para a última hora. (www. ofuxico.com.br. O fuxico. Última atualização 24/09??, 13:12. Acesso em: 4 set. 2007).

De uma forma geral, esse tipo de material procura atender as necessidades de conhecimento e informação das pessoas comuns, algumas vezes trazendo para a realidade local ou para a percepção pessoal temas abordados na mídia internacional, analisando curiosidades e tendências, enfim, tudo que diga respeito às pessoas de suas formas de agir e comportar-se. No entanto, o termo pode também ser facilmente confundido com o jornalismo de serviço ou material de interesse humano.

Ao que tudo indica o termo service journalism foi cunhado nos Estados Unidos (DIEZHANDINO, 1994, p. 75), e ao ser traduzido para o português, conservou sua relativa ambigüidade, uma vez que prestar um serviço - no caso, informar - seria a própria razão de existir do jornal e do jornalismo. No entanto, a expressão tem um campo semântico diferenciado, que se refere ao seu efeito útil de prestar assistência, de ser útil ao receptor.

Rezende (1998, p. 168) destinge as matérias de serviço como algo particular:

Reserva-se ainda uma reflexão a respeito do gênero qualificado como utilitário ou de serviço. No entendimento deste pesquisador, as matérias jornalísticas em que, supostamente, se presta algum tipo de serviço ao público não se encaixam em um gênero determinado e nem sequer dentro de uma das duas categorias, informativa e opinativa. Tanto uma reportagem como um comentário econômico podem ser de extrema utilidade pública, à medida que neles estiver embutida a intenção de esclarecer, orientar ou mesmo despertar a consciência do telespectador quanto a um problema qualquer.

Inicialmente, o termo parece estar ligado às revistas femininas ou ao jornalismo voltado para o público feminino. Bezerra (1991, p. 98-99) descreve o jornalismo de serviço como tendo como 
objetivo principal "poupar tempo e dinheiro para a leitora". Assim a expressão se ligou à idéia de mostrar algo concreto, material, de uso prático, eventualmente relacionado a um bem de consumo, a coisas que são passíveis de serem compradas, alugadas, trocadas, elaboradas.

Mas a expressão se expandiu e o jornalismo de serviço deixou de referir-se apenas a objetos para trabalhar também comportamentos e experiências. "La información que significa mayor atención a como las noticias afectarán a los lectores personalmente, a qué poden hacer frente a uno problema, cómo prevenirlo o resolverlo". (DIEZHANDINO,1994, p. 76). ${ }^{11}$

Miceli (1972, p. 62) define as matérias de serviço e/ou comportamento como aquelas que estimulam o consumo ao "fornecer ao público um modelo ético comportamental para suporte da aquisição", oferecendo "modos de consumir ligados a um estilo de vida particular e situado em algum ponto da escala de prestígio". As matérias de serviço atendem as necessidades do receptor pois, "más do que ser una fuente de información y entretenimento há llegado a ser uma auténtica 'guía para vivir'," 12 (DIEZHANDINO, 1994, p. 77) (grifo do autor)

O jornalismo de serviço é particularmente interessante para as revistas femininas, pois o seu conteúdo está sempre próximo à questões relativas a aspectos financeiros. Assim, nas revistas femininas são constantes as dicas e informações referentes ao consumo de produtos e serviços, muitas vezes previamente agendados para serem exibidos em sintonia com o material comercial.

Sobre esse ponto é necessário acrescentar que no mundo atual a idéia de cidadania passou a vincular-se ao consumo. Dessa forma, o material jornalístico que aborda diretamente ou indiretamente essa questão tem um valor simbólico significativo para os receptores, uma vez que “no tocante à massa 'excluída' de consumidores, a televisão opera, em primeiro lugar, à maneira de um mostruário da cultura material na sociedade capitalista dependente (máquinas de lavar, de costura, automóveis, batedeiras etc.)" (Miceli 1972, p. 218).

Nesse sentido, muitas matérias de serviço não só oferecem a possibilidade de consumir, como a de consumir melhor, exercendo uma função "orientadora", uma vez que oferece opções, propostas, soluções e variados tipos de informações úteis para se enfrentar a vida cotidiana.

No entanto, o jornalismo de serviço é também uma ideologia do "não-conflito, uma forma de esvaziar o real, o contraditório, o polêmico, e inocentando o próprio sistema, ou ainda uma prática de transformar o serviço noticioso em pura prestação de serviço”, acrítica, onde nada é tocado, nada

\footnotetext{
11 "A informação que significa maior atenção como às notícias afetam os leitores pessoalmente, o que podem fazer frente a um problema, como preveni-lo e como resolvê-lo".

12 "mais do que uma fonte de informação e entretenimento, pode ser um autêntico "guia de vida»".
} 
é ferido, 'todos, solidários e harmoniosamente' lutem para melhorar a sua realidade. (MARCONDES FILHO, 1989, p.16).

Também se confunde com matérias de comportamento as reportagens sobre os "fait-divers" ou matérias de interesse humano, uma expressão comum ao jornalismo, traduzida ao "pé-da-letra" do human interest do jornalismo americano ${ }^{13}$.

Mesquita (2005, p. 17) argumenta que "não há propriamente uma definição científica dos conceitos de notícia e de histórias de interesse humano" (grifos do autor), as quais considera noções operativas, forjadas no meio profissional. O mesmo autor, citando Park (In: STEINBERG,1972) as define como narrativas de mistério e paixão, emotivas e sensacionalistas. Ou, como o próprio nome já diz, são fatos que se destingem em função de uma grande carga emocional.

Perez Calderon (1970, p. 38) diz sobre as matérias de interesse humano que:

...consiste, en un amplio sentido, en el 'reflejo del modo de ser del hombre', en la presencia de los instintos y pasiones humanas - las nobles y las menos nobles - en el desarrollo de la acción informativa .(...) El lo que del hombre interesa al hombre". ${ }^{14}$

De alguma maneira, matérias de interesse humano sempre estiveram presentes no jornalismo e são receita eficiente para atrair o público, pois são uma "mistura alegre de crimes e histórias de interesse humano" (STEPHENS, 1993, p. 456).

Aparentemente, o que distingue a história de interesse humano do restante do material publicado é que sua valoração ocorre em função unicamente da sua carga emocional. Assim, enquanto a matéria de serviço tem um componente pedagógico, geralmente direcionado ao consumo ou ao comportamento público, a matéria de interesse humano, em função de sua carga moral ou moralizadora, tem esse conteúdo pedagógico voltado para o comportamento ético, doméstico, familiar.

\footnotetext{
${ }^{13} \mathrm{O}$ debate sobre a tipologia do material jornalístico é aprofundado no artigo Reflexões sobre a tipologia do material jornalístico: o jornalismo e as notícias. TEMER, Ana Carolina Rocha Pessoa. Reflexões sobre a tipologia do material jornalístico: o jornalismo e as notícias. Revista Brasileira de Comunicação. São Paulo, v.30, n.1, p. 49-70, jan./jun. 2007. TEMER, Ana Carolina Rocha Pessoa. Reflexões sobre a tipologia do material jornalístico: o jornalismo e as notícias. Revista Brasileira de Comunicação. São Paulo, v.30, n.1, p. 49-70, jan./jun. 2007.

14 “...consiste, em um sentido amplo, em 'reflexo ou modo de ser do homem', na presença dos instintos e das paixões humanas - os nobres e os menos nobres - no desenvolvimento da ação informativa .(...) é o que do homem interessa ao homem".
} 
De uma forma geral, seja classificado como matérias de serviço ou matérias de interesse humano, esse conteúdo “de comportamento" é, sem dúvida alguma, uma representação (com todos os limites impostos às representações e às distorções que elas possuem em relação ao real) de manifestações culturais de vários tipos. Sobre esse ponto é importante, ainda, acrescentar que se incluem nesta categoria todo um conjunto de material ligado às artes, representado nos programas femininos principalmente pela cultura massiva - incluindo aí moda, gastronomia, artesanato, entre outros -, mas também das chamadas "sete artes": pintura, teatro, cinema, música, arquitetura, literatura e escultura.

Nesse sentido, trabalhando a partir da noção de cultura acima descrita, fica claro que os programas "femininos" são também um espaço consolidado de jornalismo cultural. Trata-se de uma relação que, comprovada pelos aspectos históricos, apesar dos elementos empobrecedores e dos limites do formato, se renova na programação feminina apresentada na televisão brasileira.

\section{Algumas considerações:}

A percepção de que o espaço para o Jornalismo Cultural na televisão se insere dentro dos chamados programas femininos só é possível se trabalharmos a partir de uma nova concepção de cultura, na qual a cultura de massa ou os produtos culturais massivos ocupam um espaço fundamental, e de que a cultura engloba aquilo que convencionamos chamar de "comportamento humano".

Nesse sentido, as matérias de comportamento seriam/são exemplares, pois traduzem a própria cultura humana, ou uma forma de representação dessa cultura no espaço televisivo.

Mesmo considerando que cada grupo tem seus interesses pessoais, e até grandes acontecimentos quando focados pela mídia são rapidamente considerados ultrapassados, as matérias de comportamento apontam para representações possíveis da cultura.

De fato, as revistas femininas na televisão não apenas possibilitam representações da cultura, como também o fazem de uma forma plural, permitindo abordagens de diferentes modelos e de escolhas individuais, de engajamento ou de negação dos modelos propostos pela coletividade e de especificidades de públicos diferenciados.

Nestes tempos de desintegração de ruptura com um projeto de jornalismo engajado, os programas femininos, ou as revistas femininas na televisão apontam para uma mudança dos paradigmas no jornalismo cultural. O que temos agora é a definição de um novo papel para este tipo 
de jornalismo "de comportamento", que assume o papel de orientar o indivíduo, oferecendo informações das mais variadas fontes. Ou seja, as matérias de comportamento ou culturais devem servir como um termômetro da gama de interesses das mais diversas áreas.

No que diz respeito a reflexões teóricas, é preciso considerar também se esse modelo de jornalismo corresponde a um novo gênero, linguagem ou simplesmente uma temática apropriada interesse e/ou contexto dos receptores da televisão brasileira. Neste caso, qual seria a função do jornalismo de comportamento, ou cultural, ou ainda de serviço?

Nos tempos atuais em que a identidade dos indivíduos encontra-se definida não essencialmente por padrões socioculturais e as comunidades estão cada vez mais desterritorializadas e envolvidas em escolhas subjetivas, baseadas em opiniões ou atitudes isoladas, o papel do jornalismo cultural é mais do que informar, é orientar.

Essa orientação englobar diversos aspectos, inclusive o padrão de consumo. Em uma sociedade definida cada vez mais pelo lema de que "o dever primeiro de todo cidadão é ser um bom consumidor", consumir bem é essencial para que cada cidadão consiga igualmente viver bem.

Também é função desse novo jornalismo cultural "explicar” fenômenos sociais diversos, como por exemplo, o processo de mundialização na/da cultura, sem esquecer das reações representadas pelas culturas regionais ou marginalizadas que explodem e buscam afirmação nesta conjuntura e de seus elementos distintos, como as lutas étnicas e as modas alternativas em suas diversas representações culturais (música, artes, etc.).

Os receptores/consumidores devem ter suas expectativas esclarecidas por um jornalismo claro, dinâmico e eficiente. O novo jornalismo cultural, portanto, deve organizar-se segundo a ótica do serviço e da produção de informações que realmente possa servir a audiências ao mesmo tempo segmentadas e unidas por um contexto de mundialização. São estes novos parâmetros que, aliados aos fatores anteriores, devem provocar as novas reflexões no campo do jornalismo cultural.

\section{Referências}

TEMER, Ana Carolina Rocha Pessoa. Reflexões sobre a tipologia do material jornalístico: o jornalismo e as notícias. Revista Brasileira de Comunicação. São Paulo, v.30, n.1, p. 49-70, jan./jun. 2007.

BEZERRA, Ruth Joffily. Jornalismo e produção de moda. Rio de Janeiro: Nova Fronteira, 1991. v. 01. 148p.

BUITONI, Dulcília Schroeder. Imprensa Feminina. Série Princípios. São Paulo: Ática, 1986. 
CARVALHO, K. A cidade das revistas: imprensa feminina no Rio de Janeiro: anos 20. Rio de Janeiro: UFRJ/ECO, 1995

DIEZHANDINO, Maria Pilar. Periodismo de servicio: la utilidad como complemento informativo en Time, Newsweek, U.S. News, Wold report y unos apontes del caso español. Colecion Bosh Comunicación, Icaria Editorial, 1994.

LORÊDO, João. Era uma vez... a televisão. São Paulo: Alegre, 2000.

MACHADO. Cassiano Elek. A renovação cultural. Folha de S. Paulo - Caderno especial, Folha 80 anos. São Paulo: 18 fev. 2001, p.18.

MESQUITA, Mário. Teorias e práticas do jornalismo: da era do telegrafo ao tempo do hipertexto. MICELI, Sérgio. A noite da madrinha. São Paulo: Perspectivas, 1972.

O fuxico. www.ofuxico.com.br. O fuxico. Última atualização 24/09??, 13:12. Acesso em: 4 set. 2007.

PARK, R. A notícia como forma de conhecimento. In: STEINBERG, C. (Org.). Meios de comunicação de massa. São Paulo: Cultrix, 1972.

PEREZ CALDERON. La Informacion audiovisual. Madrid: Imprenta del Ministerio de Información y Turismo, 1970.

REIMÃO, Sandra (Coord.).Livros em revistas: um estudo sobre a seção de livros em revistas brasileiras de grandes tiragens. São Paulo: Faculdades Salesianas, 1996.

REZENDE, Guilherme Jorge. Perfil editorial do telejornalismo brasileiro. São Bernardo do Campo: Unesp, 1998. (Doutorado). 289p.

RIXA. Almanaque da TV - 50 anos de memória e informação. Rio de Janeiro: Objetiva, 2000.

STEPHENS, Mitchel. História das comunicações: do tantã ao satélite. Rio de Janeiro: Civilização Brasileira, 1993.

VILAS BOAS, Sérgio. O estilo magazine: o texto em revista. São Paulo: Summus, 1996.

WOLF, Mauro. Teorias da comunicação. Lisboa: Presença, 1987. 